\section{UCDNN}

LIBRARY
University of Connecticut OpenCommons@UConn

Faculty Articles and Papers

School of Law

2012

\title{
The Once and Future Networked Self
}

Steven Wilf

University of Connecticut School of Law

Follow this and additional works at: https://opencommons.uconn.edu/law_papers

Part of the Intellectual Property Law Commons, Law and Society Commons, and the Privacy Law Commons

\section{Recommended Citation}

Wilf, Steven, "The Once and Future Networked Self" (2012). Faculty Articles and Papers. 304.

https://opencommons.uconn.edu/law_papers/304 


\section{HEINONLINE}

Citation: 6 Jrslm. Rev. Legal Stud. 1102012

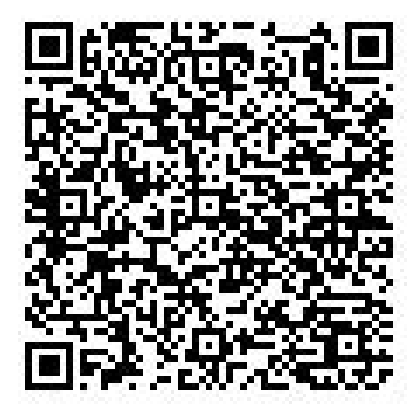

Content downloaded/printed from

HeinOnline (http://heinonline.org)

Mon Aug 15 17:34:54 2016

-- Your use of this HeinOnline PDF indicates your acceptance of HeinOnline's Terms and Conditions of the license agreement available at http://heinonline.org/HOL/License

-- The search text of this PDF is generated from uncorrected OCR text.

-- To obtain permission to use this article beyond the scope of your HeinOnline license, please use:

https://www.copyright.com/ccc/basicSearch.do?

\&operation $=$ go\&search Type $=0$

\&lastSearch $=$ simple\&all=on\&titleOrStdNo=2219-7117 


\title{
The Once and Future Networked Self
}

\begin{abstract}
Steven Wilf*
Julie Cohen's wonderfully illuminating work draws upon a wide range of philosophical literature and social criticism to suggest that being networked we fashion the self. We are joined to others - our bodies, ourselves are disembodied and linked to a vast, dizzying array of information collections, digital platforms of expression, and social media. Cohen argues that copyright plays a fundamental role in establishing how these newly digitized selves might be protected as proprietary, undergo surveillance, or be exploited in the marketplace. Cohen's copyright is a big tent understanding of copyright. If copyright is an instrument of networking, then it must be an instrument which takes into account the setting of the boundaries for these uses. ${ }^{1}$

Cohen shows how we are networked-our information mined by a new class of purveyors of information from visited websites to marketers - and the limits of our autonomy, our ability to choose as everyday practices different directions in the making of our personal identities. ${ }^{2}$ A variety of intellectual constructs make the construction of the self more difficult in a digital environment. Access to knowledge and network neutrality, providing for equitable public rights to use digital information, has overvalued informational exchange. ${ }^{3}$ These are often seen as a good in its own right. Cohen, instead, takes a sophisticated functional approach, and asks to what extent digital architecture, shaped by either technology or legal norms, contributes to human flourishing.

Today, as Cohen points out, we are experiencing an enormous increase in the amount of networked information on a scale never before envisioned. Part of this is due to the growth of security information collection in the wake of
\end{abstract} concerns with international terror. Western governments are collecting data about citizens, potential non-state terrorist actors, and, in short, from individuals who might never have previously come under surveillance as potential security threats. Part of this is a consequence of an increasingly market-based Western economy that has staked its future on its ability to sell to consumers

\footnotetext{
* Joel Barlow Professor of Law, University of Connecticut. Email: steven.wilf@law.uconn.edu. $(2012)$.

Julie E. Cohen, Configuring the Networked Silf: Law, Code, and the Play of Everiddy Practice

2Id. at 30

3 Id. at $261-62$ and $219-20$.

The Author 2013. Published by Oxford University Press and the Hebrew University of Jerusalem. All rights reserved. For Permissions, please email: journals.permissions@oup.com
} 
rather than to produce new goods. Knowing an individual's desires, purchasing habits, the extent of his or her economic resources, and the constellation of previous transactions, can provide for the construction of a reservoir of powerful marketing information. But even the supposed Jimmy Deans of the virtual world-those mobilizing others to support pirate parties, NGOs such the Electronic Frontier Foundation and shareware advocates, or ad hoc political action such as that which was successfully marshaled to halt the passage of the Stop Online Piracy Act (SOPA) - benefit from collecting information about a robust network of digital citizens.

\section{Introduction}

Copyright has often been seen as teleological-as serving to promote public welfare through the creation and dissemination of expressive works. Bolstered by a robust Anglo-American utilitarian framework, this commonplace quite simply identifies the growth of available expression. Such an approach focuses on the expressive object. It might be created, protected, accessed. But, in all cases, this is for the benefit of society as a whole. Cohen's point of departure is her identification of human flourishing as the cornerstone for understanding the importance of creating conditions for promoting the individual's capabilities within a complex web of ideas, language, and culture. ${ }^{4}$ Drawing upon Amartya Sen, Martha Nussbaum, and the ancient Greek concept of eudaemonia, she speaks of human flourishing as the mobilization of resources so that the self might, quite simply, become a fully developed self. ${ }^{5}$ Eudaemonia is a central concept of Aristotelian ethics, and, as Aristotle points out, such ethical considerations must pertain to individuals in different ways because while people agree that it is important to live well, "many do not have the same sense of account.."

In order to develop this self-flourishing, Cohen relies upon the notion of play. Play, for her, is a site of experimentation, a practice of everyday life, which might use the expression of others in kaleidoscopic remixing, when it is partly bounded and unbounded - both open and closed, a space that is free from surveillance, a fashioning that is very much a matter of process than a fixed creation, and performative in a way that defines the scope of the audience from either one's own gaze to a broader audience. It is not difficult to imagine current digital genres as embodiments of this play activity. We are e-homo lindens in our blogs, slash fiction, and gaming avatar personae.

Perhaps the chasm between the promise of an internet utopia and the everyday practices of information movement, between the ideal and the actual would

\footnotetext{
4. 1 at 22 .

5 See, for example, Amartya K. Sen, Capability and Well-Being, in The OUALTY of LIFE $30-53$ (Martha Nussbaum and Amartya K. Sen eds., 1993) and Martha Nussbaum, Womex and Humar Development: Thi CAPABILITIES APPROACH (2000).

'A Aristotle, Nicomachean Eihics, Book X: 19-20, in THE Complete Works of ARIStotle, The Revised OXford TranslamoN 2: 1730-31 Jonathan Barnes ed., 1984).
} 
not be so notable if it was not that a consensus has been established with a default of strong rights in information and weak rights in privacy. ${ }^{7}$ It is Cohen's very significant contribution that she asks, no demands, that we rethink this legal commonplace. But Cohen goes one step further. For her, the debate is not the competition between proprietary rights in intellectual property-the bundles of rights necessary to use, alienate, and reap profit through licensing expression - and the rights of others to exploit these free of rent-seeking monopolies in the public domain. Instead, she seeks a balance, almost an Aristotelian mean, between information utilization and the protection of a site for play.

Cohen is perplexed that the "emerging regime of information rights and privileges is publicly justified in terms of economic and political liberty, but as a practical matter it allows individuals less and less control over flows to, from, and about themselves." ${ }^{98}$ However, the gap between rhetoric and reality is a commonplace in Anglo-American political discourse about property. Jeffersonian notions of land grounding the liberty of autonomous farmercitizens was marshaled by slave holders to justify the control of bound labor. Free labor arguments in the north became the basis for an extensive system of poorly compensated industrial laborers-what southern critics would call wage slavery. In our own time, the Property Right Movement with its emphasis upon liberty has sought to bolster private ownership rights - even though these may cause even more limitations upon the ability of ordinary citizens to use their property in the fullest fashion because of the barriers to collective action.

The networked self is linked and unlinked to others, and always in the process of linking and unlinking. Cohen understands play as requiring both a relationship to the expressive object-the text, the image-and a connection to a web of creators, users, and observers. It is surprising that in a lineup of first-string cultural critics that Cohen conjures up, including Nussbaum, Johan Huizinga - the author of the classic work on play, Homo Ludens, Michel Foucault, and Hans-Georg Gadamer, that Roland Barthes did not make a cameo appearance. Barthes's notion of jouissance encompasses one of the most important aspects of Cohen's everyday practice of play. According to Barthes, the playful pleasures of text which are so essential to self-fashioning requires a text which changes the reader's position as a subject by allowing him or her to become a composer, redactor, or significant critic who reorders the text. Barthes calls such a text scriptible text. By this he means a text that conditions writing, or something akin to writing, for another. ${ }^{9}$

While Cohen treats the networked self as embodied, this embodiment has not been traced across time. In these brief comments, I will argue that the network self has both a past and the future. The past is located in a series of

\footnotetext{
${ }^{7}$ CoHEN, supra note 1 , at 3 .

${ }^{8}$ Id. at 3 .

9 Roland Barthes, Le Plaisir Du Texte (1973).
} 
philosophical and doctrinal postures which presume that copyright is simply part of a much broader network of ways that knowledge might be mediated. Texts operated as extensions of the self within social networks, sometimes disembodied and sometimes kept closely watched by their creators, and rarely as commoditized or scrutinized as textual expression today. I will argue for a "once" networked self that begins in the renaissance, but remains very much at the core of copyright in the formative period of American copyright law, the end of the eighteenth century, when United States copyright was envisioned as a lynchpin of citizenship within a political framework deeply influenced by a transatlantic republic of letters.

The future networked self is emerging in Europe. I particularly original fashion, Cohen insightfully couples two disparate parts of law, copyright and privacy, and shows how they are inextricably linked. She argues for a balance between what expression is made proprietary, and subject to alienation, commodification, licensing, and, perhaps, data mining as part of broader information collection within consumer markets, and expression which must be shielded from surveillance. The European Union has identified ownership of databases not as copyright, but as droits voisins, neighboring rights. As a consequence, the balance between a weaker proprietary right in information and a stronger human right in privacy has created a tension which has led Europeans to provide more space for the playful networked self. This "future" networked self is the subject of the second part of this article.

\section{The once networked self: authorship in its circle}

The networked self, of course, is an historical persona. He or she was networked by being part of a territorial unit such as a village or even a nation state, networked through religious practices, networked through convivial associations, networked through occupation by means of guilds and, later with the rise of professions, through professional societies. Sometimes, as in the case of the literary salon, the networks were voluntary and occasional. Such networks, Jürgen Habermas famously argued, was critical for creating the emerging public sphere at the root of Western political culture, what he called Öffentlichkeit. ${ }^{10}$

Copyright, at least modern copyright statutes, are creatures of the modern era. Erasmus and the humanists created a culture of sharing works under the rubric "friends hold all things in common." As Kathy Eden has shown in her book with the same title, early modern commonplace books gathered adages from a vast array of classical sources as expressions of the self and as a gift

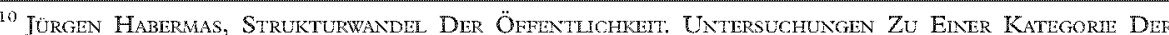
Búgirlicher Gestllschaft (1962), translated by Thomas Burger AND Friderick Lawrence as Thi Structural Transformation of the Public Sphere: An Inguiry Into A Category of Bourgeois Society (1991).
} 
bestowed within certain literary circles. Early copyright was born within this republic of letters. ${ }^{11}$ To be sure, various forms of controls - censorship by the state and guild restrictions on printing enforced by printers through the Licensing Act in Britain - set the terms of how information would be constructed and circulated. The Statute of Anne (1710), which became the model for the earliest United States copyright statutes passed by states in the 1780s and the Federal 1790 Copyright Act, focused on potential harm to the author. Some of this harm was economic, failure to capture the economic rewards of publication led "too often to the ruin of them and their families."

But in the American context, republican authorship functioned under the conception that authors operate within literary and political circles-sharing most books without copyright. Publishing was a performative act within these circles: staking out positions, identifying the self. Few works were copyrighted. Some of the early state statutes referred to the purpose of copyright as the encouragement of genius. By genius, the eighteenth-century architects of American copyright did not mean a romantic notion of the unbridled creator, but the revelation of the individual self.

What does it mean to encourage genius? During the end of the eighteenth century a series of literary works, including William Sharpe's $A$ Dissertation upon Genius (1755), Edward Young's Conjectures on Original Composition (1759), William Duff's, An Essay on Original Genius (1767), and Alexander Gerard's, An Essay on Genius (1774), debated the meaning of the term. Part of this debate was about the relative importance of natural and acquired ability. Young's essay comes out particularly strongly in favor of innate genius, which emerges like Athena from the head of Zeus. The debate over genius was perhaps the most extensive literary discussion in vogue during this period. By the end of the eighteenth century, it was bound up with politics. William Godwin's Of the Sources of Genius (1797) argues against intellectual inequality. Given the proper conditions, ordinary people also can develop the capacity to create strikingly original literary works. The self could best be developed through the absence of patronage.

Authorship has received its share of bad press in copyright circles. Peter Jaszi and Mark Rose launched a major critique of how copyright doctrine has been shaped, and misshaped, by romantic notions of authorship. Catherine Fisk, more recently, has shown how the work made for hire doctrine identified the centrality of actual authorship with the owner of a commodity. Cohen has proposed a new model for authorship one that seems to be true to the origins of modern Anglo-American copyright law in the eighteenth century by insisting that the author as borrower, performer, and creator of the self stands at the center. Borrowing, of course, is a critical first step. Literary critic Joseph Campbell

\footnotetext{
11 Kathy Eden, Friends Hold all Things in Common: Traditong Intellectual Property and the Adages of Erasmus (2001).
} 
famously argued in a Hero with a Thousand Faces, that there is one basic plot, the hero's journey, though others have listed variations upwards to two dozen (such as the quest, rivalry, maturation, forbidden love, sacrifice). We all borrow to create mélanges. But Cohen, more importantly, argues that we borrow first to create ourselves.

Should mere use as a consumer or a borrower be favored by the law? Cohen calls this the "romantic user." 12 We can imagine, for example, a case such as that of Albert $\mathrm{C}$. Barnes who took the paintings of others and created a remarkable set of connections among them in his display of these works of art at the museum founded in Merion, Pennsylvania. But not every user is constructing the self. Some are free riders utilizing the works of others without any sort of payment, some are merely cheap. How do we distinguish these two types of figures in Cohen's scheme? And do we need to do so?

The right to borrow for personal use is critical, Cohen argues, for the flourishing of the self. "Expressive liberty," to use her term, requires the making of a domestic or personal environment, the using of materials in mélanges or pastiches such as through sampling and remixing music, and the establishing of a creative sphere where the self can develop in autonomous fashion. It might even demand the posting of favorite songs or the appropriation of treasured written texts in the setting of social media.

Borrowing, too, was a major feature of late eighteenth-century American copyright law. The early state copyright laws of the 1780 s, which emerged during the American Revolution and directly preceded the Federal Copyright Act of 1790 , included a provision which was meant to ensure that useful books would be available for borrowing expression at a reasonable price. These laws provided for a public action in court whenever an author or publisher failed to furnish the public with sufficient number of editions or set the price too high. Taking into account labor costs, time, the expense of production, and the risk of sale, the author had a right to reasonable compensation, but not to charge more than the just price. After a legal complaint was filed, a state judge would summon the owner of the copyright to appear before the court. A court might order the publisher to print additional copies of the work at a set price. If the owner of the copyright refused to comply, the court might assign to the person making the complaint a license to reprint copies. Expression was seen as a necessity-much like food or other basic commodities-and therefore must be made available at a just price. ${ }^{13}$

When the Federal Copyright Act of 1790, the first copyright law grounded upon the Constitution, went into effect, it was only half of a broader regulation

\footnotetext{
12 Cohen, supra note 1 , at 68

${ }^{13}$ Steven Wilf, The Moral Lives of Intellectual Properties, in Transformatons in AMerican Legal History: Essays in Honor of Professor Morton J. Horwitz 344-68 (Daniel W. Hamilton and Alfred L. Brophy eds., 2009).
} 
of printed texts. Just two years later, as a close kin to the book-centered 1790 law, a statute was passed in 1792 to facilitate borrowing. From the very beginning of newspaper publication in the United States material was taken from one printed gazette and published in other newspapers. In the eighteenth century, articles were simply lifted, often without attribution. Indeed, it was customary for postmasters to allow newspapers to be exchanged with other printers without any charge for postage by local postmasters. ${ }^{14}$ This informal mechanism of spreading the news was subsidized by the post office. Congress passed the 1792 statute to facilitate this exchange by allowing every printer to send a newspaper to any other printer within the United States free of postage. ${ }^{15}$ The postal exchange was intended to promote the appropriation of news, rather than - as the Supreme Court would decide in International News Service finding it to be misappropriation.

Yet borrowing alone is insufficient. Cohen clearly also recognizes that the self is by its nature performative. There is a need to express one's likes and dislikes, identifying how an individual responds to the external world, and to exercise control over the presentation. This might take place in a variety of new digital genres such as blogs or slash fiction or within the role playing collective environs of digital gaming. Selfhood-as the Marquise de Merteuille learns in Les Liaisons dangereuses - is forged in the eyes of others.

Cohen's two critical moves for reworking the concept of authorship-understanding the importance of borrowing and performing - prompts her to rethink copyright. Should there be a personal use exception to copyright infringement? How can use be a part of authorship of the self even when it is not transformative to the work as is required by the first prong of the American test for fair use? And, most importantly, how can individuals establish greater control over the performative presentation of the self?

\section{The future networked self: network controls and boundary tending}

The internet has commonly been portrayed as a locus of market and expressive liberty - as a democratic forum and as a market with lower transaction costs. Information has become a commodity (Kaufware-in Marx's language). Cohen adds privacy to the terms of the debate. What is the source for privacy? Human dignity - fundamental trumping right, or, perhaps, it is a sociological framework of personhood. In any event, theories of privacy are "socially constructed" and therefore have difficulty asserting its place as a fundamental

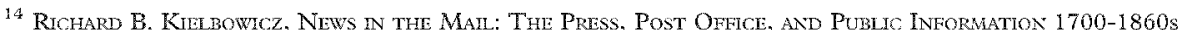
(1989), 141 ff.; David M. Hienmin; The Postal Age: The Emergerce of Moderi Communtcations in Nineteenth-Century America (2006), pp. 42-43.

15 Act of Feb. 20, 1792,1 U.S. Statutes at Large 238.
} 
right (19). Much of the privacy literature has become consumed with its role as a trumping right - and the dilemma of how to craft such a right when notions of privacy are culturally contingent. But Cohen throughout her book is interested in process with all its messy complexity. How does privacy operate to fashion the autonomous self? Privacy in its traditional sense is about constructing spheres of autonomy. Prosser's four prong privacy tort, for example, has entailed publicly disclosing private facts about the plaintiff or unreasonably intruding upon the seclusion or solitude of the plaintiff. According to this definition, privacy is domestic, secluded, set apart - in short, un-networked.

Trade secrets, the Computer Fraud and Abuse Act of 1984 (CFAA) - what a marvelous name - and the Digital Millennium Copyright Act of 1998 (DMCA) are all access limiting mechanisms for distinguishing between a private or controlled sphere of information and a public sphere of open, unfettered access. But the spatial model is already passé. Our selves need-in order to flourish as borrowers and performers - to be networked selves.

\section{Matrix reloaded-towards privacy protection}

At a certain point in the film, Matrix Reloaded, Councilor Harmann says to Neo, "sometimes I think about all those people still plugged into the Matrix and when I look at these machines I... I can't help thinking that in a way... we are plugged into them." Neo interjects, "but we control these machines, they don't control us." "Of course not," Harmann responds, "The idea is pure nonsense, but it does make one wonder: just what is control?"

Cohen's book prompts the same question: "just what is control?" Cohen is terribly clever at carving out a new cultural direction for copyright, for breaking ourselves free of the $\mathrm{A} 2 \mathrm{~K}$ mantra that more information is always better, for moving to a 2.0 model of constructing a digital environment beyond Lawrence Lessig's focus on mechanisms of technological and legal control to one where being linked creates possibilities and dangers for the construction of a flourishing self, for redefining copyright's role in establishing the terms of authorship as promoting the authorial self. Above all, by asking what does it mean to create, Cohen has brought us the three "c"s-culture, complexity, and contingency.

But if Cohen's book is a manifesto (and I hope it is), then how should it be implemented? Take the issue of privacy. Cohen would like us to weigh the benefits and costs to data collection in both economic and, especially, cultural terms. How invasive of privacy is the data collection? Are there legitimate reasons for performing the surveillance? Should this information be captured for a longer amount of time or remain simply transitory? To what extent is this information aggregated in ways to suggest the dimensions of an individualhealth, credit card, browsing habits. 
Cohen argues that access to knowledge should include a commitment to privacy. What she really means is that there should be different sorts of knowledge. Some knowledge should be controlled much as authors have traditionally exercised power over deeply personal aspects of their lives that are bound up with the self. Under the American 1909 Copyright Act, expression was protected by common law copyright until either registration or divestive publication occurred and the work was protected or released into the public domain. In United States fair use analysis, greater protection is granted to the original author for pre-published material. French moral rights law provides a special protection to artists, the droit de divulgation, to select the time and place when a work will be first displayed. The United States Section 106 rights of performance and display vest similar rights in the copyright owner.

But digital, networked information does not have such a simple private/ public or before release/after release distinction. Article 8 of the European Convention on Human Rights and Articles 7 and 8 of the Charter of Fundamental Rights of the EU protect rights of privacy and the confidentiality of communication. But what practical steps might be designed to ensure privacy in a networked world? One way to limit data access might be to create a Trusted System as Cohen describes - a limited envelope for personal access and use of web materials. I2P, a computer network layer that provides anonymity, is another example.

We could have limitations requiring access to be granted by courts. The EU Data Retention Directive (Directive 2006/24/EC), for example, requires member states to store citizens' telecommunications data for six to 24 months stipulating a maximum time period. Under the directive the police and security agencies will be able to request access to details such as IP address and time of use of every email, phone call and text message sent or received. A permission to access the information will be granted only by a court. Such a system might require specialized tribunals similar to FISA (Foreign Intelligence Surveillance Act) courts in the United States to determine whether information distribution is unwarranted. This could occur with a process similar to notice-and-take down under the Digital Millennium Copyright Act (DMCA), though the dismal results of both FISA and the DMCA provisions suggests this might not be the best route.

We could adopt opt in/opt out rules. This might be done in a very specific fashion using something akin to P3P Platform for Privacy Preferences Project. But asymmetrical bargaining relationships might mean that waivers are not completely free. And what happens if consumers feel they benefit for either price or information costs when their purchase data is readily available? Could the lack of concern of the majority for an expectation of privacy interests shift our norms as a whole?

We could limit surveillance to legitimate interests. The EU Data Protection Directive, 95/46/EC states data must only be collected for "specified, explicit 
and legitimate purposes and not further processed in a way incompatible with those purposes." An Italian court in 2011 decided that internet providers are not permitted to monitor users in order to prevent copyright infringement. But these might be broadly interpreted. Under traditional police power, the state has a broad legitimate interest in matter of public health. Should medical data be disaggregated? And security concerns seem so often to justify the unjustifiable.

Most disturbing, vast amounts of data can currently be collected by employers about their employees in order to more efficiently direct their business operations. Would not a court - at least in the United States - find this legitimate? The most important story might not be the one about creativity and the self told in Cohen's book, but the use of data as levers to maximize productivity in a kind of new version of Taylor's time and motion studies.

We could limit the individual identification of data; require the removal of certain data after a given period; require transparency about when information gathering systems are operating; or limit the place and time of surveillance. There is a fairly new Danish penal code provision against posting photographs of individuals in public areas on the internet. But would any of this really allow for the kind of linked in/linked out model that Cohen suggests?

\section{Conclusion}

According to Cohen, we are all authors now. Cohen has reconstructed a model of the expressive self that is deeply rooted in the original eighteenth-century conception of copyright as borrower and performer. She has identified the importance of control over expression, privacy as well as proprietary, for the making of this authorial self, and has urged the inclusion of privacy into the house of copyright.

Above all, Cohen takes us away from a number of newer models and back to an older paradigm. Copyright is not purely a utilitarian mechanism for providing incentives to create and disseminate expressive works. This model, often grounded upon a view of the creator as a one-dimensional economic actor, has little allure for Cohen. It fails to capture the complex motivations behind the making of written and artistic works. Nor does Cohen see copyright as subsumed within the framework of a new virtual world created through information technologies. She is rightly skeptical of grandiose claims that virtual worlds are separate juridical space with its own normative rules. Indeed, as she correctly points out, cyberspace is inhabited by embodied individuals - and, borrowing from Shakespeare, "do not embodied individuals have their own hands, organs, dimensions, senses, affections, passions." Are they not "fed with the same food, hurt with the same weapons, subject to the same diseases heal'd by the same means, warm'd and cool'd by the same winter and summer" as those outside of virtual worlds? 